\title{
Problems of Escherichieae Systematics and the Classification of Atypical Dysentery Bacilli
}

\begin{abstract}
WOLFGANG STENZEL
Bakteriologisches Untersuchungsamt des Kreises Wesel in Moers, D-4130 Moers, Germany

Due to the close systematic relationships within the tribe Escherichieae, definition of the taxon Shigella should be based primarily on the potential enteropathogenicity of the dysentery types. Immobile and anaerogenic dysentery bacilli possessing biochemical activities exceeding the established Shigella norm could be included in Shigella subgroup $\mathrm{D}$, to which should be given the name $S$. metadysenteriae to avoid misunderstandings resulting from lipopolysaccharide phase designations I and II of S. sonnei. S. sonnei, serotype 792 and serotype 147, and S. guanabara are proposed to be listed as serotypes 1 to 4 of S. metadysenteriae. Regularly aerogenic and/or motile dysentery types of the tribe Escherichieae-E. coli $0124,0136,0143,0144$, and 0152 -could be placed for the present into a provisional taxon Escherichia dysenteriae.
\end{abstract}

Some years ago, Manolov, Trifonova, and Stenzel $(7-10,14,15)$ suggested a definition of the genus Shigella based on the potential pathogenicity of freshly isolated Shigella strains for the conjunctivae and urinary bladder of guinea pigs. The authors made this proposal because they felt that there are no other peculiarities suitable for discriminating between Escherichia and Shigella (cf. 9). In 1962, however, the Enterobacteriaceae Subcommittee (5) decided that such pathogenicity tests should not be accepted as a criterion for the inclusion of an organism in the Shigella group.

In the meantime our presumption as to the systematic relationships between Escherichia and Shigella has been widely confirmed by further findings (cf. 12), especially by fairly precise analysis of polynucleotide relatedness between strains of these taxonomic groups (1-4) and by the discovery of an overlapping protein antigen typical for all dysentery bacilli $(11,16)$. On the other hand, it became apparent that Shigellalike pathogenicity for mucous membranes is not limited to the Shigella group but can also be found in certain motile and aerogenic Escherichieae. Although we have been able to judge the enteropathogenicity of almost any Escherichieae bioserotype, we, nevertheless, did not find until now a stable marker connected with pathogenicity and so have been unable to demonstrate this property in every individual case.

As matters stand, the question arises whether the taxonomy of the tribe Escherichieae Bergey et al. 1938 emend. Ewing 1963 should reflect a part of history of bacteriological nomenclature, or whether it should be based on facts or should take its bearings from the needs of medical mi- crobiologists. It is our opinion that there is no doubt that Escherichieae taxonomy will one day be set up by the necessity of separating dysentery bacilli from apathogenic or only toxinogenic Escherichieae. Current thinking in classifying unusual dysentery types does not lead to an acceptable situation. One can, for example, denominate serotype 147 strains as $E$. coli $O 25$ on the grounds of serological relationships, but when the entire background is taken into consideration, i.e., pathogenicity, biochemical behavior, presence of certain protein antigens (17), and differences in the chemical composition of the O-lipopolysarrharides concerned (13), one realizes that such nomenclature is of little value both for practical and theoretical purposes.

It may seem premature to set up a new classification of the tribe Escherichieae Ewing 1963 before having in hand the chemical substances responsible for pathogenicity of the dysentery types. One must consider, however, that pathogenicity for mucous membranes is a property of little genetic stability which may lose its traceability by chemical methods together with its demonstrability in animal tests. It is true, that, for lack of stability, pathogenicity for mucous membranes cannot serve as a taxonomic criterion without reservation, and therefore it might be wise not to cite animal tests when setting up formal definitions concerning the tribe Escherichieae. However, positive results of pathogenicity tests on a certain Escherichieae strain should be considered in any case when judging the taxonomic position and nomenclature of the bioserotype represented by the culture in question.

As already stated $(9,10,12)$ Shigella subgroup 
D should be open for inclusion of any immobile and anaerogenic dysentery type that possesses a biochemical activity exceeding the Shigella norm, for example those that split lactose, salicin, acetate, mucate, or citrate, as long as such strains are not biotypes of Shigella types already accepted. The specific epithet of $S$. sonnei, however, should be dropped to avoid misunderstandings resulting from lipopolysaccharide phase designations I and II of S. sonnei (9). Instead of the latter name we suggest the name $S$. metadysenteriae Stenzel 1962 (9) for Shigella subgroup $\mathrm{D}$, and that $S$. sonnei be listed as $S$. metadysenteriae 1 , serotype 792 be listed as $S$. metadysenteriae 2 , serotype 147 be listed as $S$. metadysenteriae 3 , and $S$. guanabara (" $E$. coli $0112 \mathrm{a}, \mathrm{c}$ ") be listed as $S$. metadysenteriae 4 .

The second, more Escherichia-like group of atypical dysentery bacilli could remain within the genus Escherichia but then should be placed into a provisional species $E$. dysenteriae which would comprise at the present time $E$. coli serotypes $0124,0136,0143,0144$, and 0152 (cf. 12). A formal definition of a $\operatorname{tax}$ En $E$. dysenteriae could hardly exceed the statement that $E$. $d y$ senteriae should contain any Escherichieae type that causes dysentery but is regularly aerogenic and/or motile. Such a separation of a species $E$. dysenteriae might not be easily accepted but is the necessary compromise for the protection of the Shigella biotype concept.

\section{REPRINT REQUESTS}

Address reprint requests to: Dr. Wolfgang Stenzel, Bakteriologisches Untersuchungsamt des Kreises Wesel in Moers, Goethestr. 1, D-4130 Moers 1, Germany.

\section{LITERATURE CITED}

1. Brenner, D. J., G. R. Fanning, K. E. Johnson, R. V. Citarella, and S. Falkow. 1969. Polynucleotide sequence relationships among members of Enterobacteriaceae. J. Bacteriol 98:637-650.

2. Brenner, D. J., G. R. Fanning, G. V. Miklos, and A. G. Steigerwalt. 1973. Polynucleotide sequence relatedness among Shigella species. Int. J. Syst. Bacteriol. 23:1-7.

3. Brenner, D. J., G. R. Fanning, F. J. Skerman, and S.
Falkow. 1972. Polynucleotide sequence divergence among strains of Escherichia coli and closely related organisms. J. Bacteriol. 109:953-965.

4. Brenner, D. J., G. R. Fanning, A. G. Steigerwalt, I. Orskov, and F. Orskov. 1972. Polynucleotide sequence relatedness among three groups of pathogenic Escherichia coli strains. Infect. Immun. 6:308-315.

5. Enterobacteriaceae Subcommittee. 1963. Minutes of Enterobacteriaceae Subcommittee Meeting, Montreal, August, 1962. Int. Bull. Bacteriol. Nomen. Tax. 13:139-143.

6. Ewing, W. H. 1963. An outline of nomenclature for the family Enterobacteriaceae. Int. Bull. Bacteriol. Nomen. Tax. 13:95-110.

7. Manolov, D. G. 1959. A new type of the genus Shigella-"Shigella 13". J. Hyg. Epidemiol. (Praha) 3:184-190.

8. Manolov, D. G., and A. Trifonova. 1962. Supplements to the international classification schema of Shigellae. Works Res. Inst. Epidemiol. Microbiol. (Sofia) 8:1-8.

9. Stenzel, W. 1962. Sh. scholtensii und Sh. manolovii-zwei zur Untergruppe D zu stellende provisorische Shigella-Typen. Z. Hyg. Infektskr. 148:433-444.

10. Stenzel, W. 1964. Classification of the "coliform" serotypes 792 and 147. Int. Bull. Bacteriol. Nomen. Tax. 14:15-16.

11. Stenzel, W. 1975. Das kathodisch wandernde Gruppenantigen der Dysenterie-Erreger bei intermediären $E s$ cherichieae-Typen. Zentralbl. Bakteriol. Parasitenkd. Infektionskr. Hyg. Abt. I Orig. Reihe A 232:468-472.

12. Stenzel, W. 1975. Zur Typologie und systematischen Stellung der intermediären Escherichieen-Typen unter besonderer Berücksichtigung ihrer Schleimhautpathogenität. Zentralbl. Bakteriol. Parasitenkd. Infektionskr. Hyg. Abt. I Ref. 243:97-146.

13. Tekelieva, R. 1975. Immunochemical studies of the lipopolysaccharides of "Serotype 145-46" (Enterobacteriaceae). Zentralbl. Bakteriol. Parasitenkd. Infektionskr. Hyg. Abt. I Orig. Reihe A 231:92-96.

14. Trifonova, A. 1960 . On the classification of dysentery bacteria in Bulgaria in connection with the discovery of rare serological types. Works Res. Inst. Epidemiol. Microbiol. (Sofia) 7:45-53.

15. Trifonova, A. 1965 . Uber die taxonomische Stellung einiger Vertreter der Familie Enterobacteriaceae. Zentralbl. Bakteriol. Parasitenkd. Infektionskr. Hyg. Abt. I. Orig. 195:470-482.

16. Trifonova, A. 1968. On the taxonomy of some members of the Enterobacteriaceae family. Zentralbl. Bakteriol. Parasitenkd. Infektionskr. Hyg. Abt. I. Orig. 208:399-404.

17. Trifonova, A., and R. Tekelieva. 1968. On lactosepositive variants of Sh. flexneri $2 \mathrm{a}$ and serotype 145-46. Zentralbl. Bakteriol. Parasitenkd. Infektionskr. Hyg. Abt. I. Orig. 209:196-203. 